\title{
Biplot analysis of seed priming effects on maize seedling growth traits
}

\author{
Petar Čanak* · Milan Mirosavljević · Miroslav Zorić · Mihajlo Ćirić · Bojana Vujošević · \\ Bojan Mitrović · Dušan Stanisavljević
}

Institute of Field and Vegetable Crops, Maksima Gorkog 30, 21000 Novi Sad, Serbia

\begin{abstract}
Summary: The objectives of this study were to determine the effects of different priming treatments and genotypes on maize germination and early seedling growth traits, as well as to examine the associations among these traits. In addition, the application of genotype by trait biplot methodology in this type of analysis was evaluated. Seed priming treatment was conducted on ten maize inbred lines by soaking seeds in water (hydropriming) or in $0.5 \% \mathrm{KNO}_{3}$ solution. Seed was sown in sterile moistened sand and placed at suboptimal $\left(15^{\circ} \mathrm{C}\right)$ and optimal temperature $\left(25^{\circ} \mathrm{C}\right)$ for seven days. After that, seedling length and seedling weight were measured, final germination, time to $50 \%$ emergence and vigour index were calculated. The results showed that seed priming can improve seedling growth traits at both temperatures. There are differences in genotype responses to various seed priming solutions. The observed differences represent useful information for the selection of adapted maize inbred line and adjustment of priming treatment for sowing in different temperature conditions. This study showed that biplot could easily be used for assessing the effect of seed priming, or some other treatment, on seedling growth traits. Moreover, it can be used to understand the associations among the seedling growth traits.

Keywords: genotyping, hydropriming, maize, priming, seedlings, seeds, solutions
\end{abstract}

\section{Introduction}

Low temperature is one of the most important environmental factors that have adverse influence on plants' growth and development. It also has negative effects on seedling emergence and stand establishment (Farooq et al., 2008). Since maize can be classified as a cold-sensitive plant, suboptimal temperature and early spring frost, that are very common in agro-climatic region of Serbia, frequently reduce speed and the percent of seedling emergence.

Different pre-sowing seed treatments are often used to improve seed germination and early seedling growth in various crops. One of the commonly used pre-sowing methods is seed priming treatment, which includes partial seed hydration to initiate germination process. After that, seeds are dried to stop radicle emergence. The priming techniques that are most often

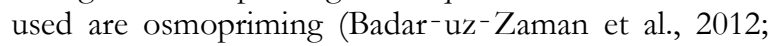

Corresponding author:

petar.canak@ifvcns.ns.ac.rs

Acknowledgment:

This study is a part of the project TR 31073 (Improvement of maize and sorghum production under stress) financed by the Ministry of Education, Science, and Technological Development of the Republic of Serbia.
Chen et al., 2010), hydropriming (Casenave \& Toselli, 2007), solid matrix priming (Pandita et al., 2010) and hormonal priming (Yazdi et al., 2013). Seed priming treatments improve seed germination rate and seedling establishment at suboptimal conditions (Čanak et al., 2014; Jafar et al., 2012; Bejandi et al., 2009). Positive effects of different seed priming methods under suboptimal temperature have previously been reported in maize (Guan et al., 2009; Farooq et al., 2008).

The most common statistical analysis for priming trials data interpretation is the analysis of varianceANOVA (Foti et al., 2008; Shim et al., 2008). ANOVA is an additive model that identifies the presence of interaction between traits across genotypes, but does not analyse the level of interaction. Multivariate analysis, such as biplot, simultaneously observes the relationship among all the examined traits that are shown in multivariate plan, while simple correlation analysis observes association between two traits, disregarding the influence of other traits (Yan \& Kang, 2003).

Multivariate analysis includes a set of techniques for simultaneous analysis of data sets with more than one variable. One of the commonly used multivariate analysis methods is principal component analysis (PCA). PCA is a mathematical method that reduces the dimensionality of the data while retaining the highest 
part of variability in the data set (Jolliffe, 2002). Mainly, the first two PCAs are shown at biplot (Yan \& Rajcan, 2002), since they usually explain the largest part of data variation. Since genotype and genotype by environment interaction (GGE) are relevant for cultivar evaluation, Yan et al. (2000) developed methodology, termed GGE biplot, for graphical analysis of multi environment trials data. Another important application of GGE methodology is genotype by traits (GT) biplot (Yan \& Kang, 2003). GT biplot allows cultivar evaluation on the basis of the multiple trait data, the interpretation of relationships among traits and the identification of genotypes that have desirable traits (Yan \& Rajcan, 2002). Genotypes that are superior in certain traits could be used for further cultivation and breeding program.

The first objective of this study was to: i) determine the effect of different priming treatments and maize genotype on germination and early seedling growth traits, ii) examine the association among these traits, and iii) evaluate the application of PCA analysis and GT biplot methodology in the results presentation.

\section{Materials and Methods}

Seed of ten maize inbred lines, developed at the Institute of Field and Vegetable Crops, Novi Sad, Serbia were used in this study, conducted in 2014 (Table 1). Only visually healthy maize seed, produced in the preceding season, was selected for the experiment. Seed priming treatments were conducted by soaking seeds in water (hydropriming) or $0.5 \% \mathrm{KNO}_{3}$ solution at $25^{\circ} \mathrm{C}$ for $17 \mathrm{~h}$. After each treatment, seeds were rinsed under tap water and then dried on filter paper at room temperature to the original moisture. Primed seed and control (untreated seed) were sown in plastic pots $(21 \times$ $15 \mathrm{~cm})$ containing sterile moistened sand $(7 \%$ distilled water) at the depth of $10 \mathrm{~mm}$. The experiment design was completely randomized with tree replicates. Testing was carried out in growth chamber, with 50 seeds per

Table 1. Maize inbred lines

\begin{tabular}{ccc}
\hline Code number & Name & Heterotic group \\
\hline 1 & $21 \mathrm{NS} \mathrm{Rf}(\mathrm{s}+\mathrm{c})$ & Lancaster \\
2 & $462 \mathrm{NS}$ & BSSS \\
3 & $118 \mathrm{NS}$ & BSSS \\
4 & $732 \mathrm{NS}$ & Iodent \\
5 & $568 \mathrm{NS}$ & BSSS \\
6 & $316342 \mathrm{NS}$ & Lancaster \\
7 & $230177 \mathrm{NS}$ & Lancaster \\
8 & $250119 \mathrm{NS}$ & BSSS-Iodent \\
9 & $260815 \mathrm{NS}$ & Ohio 43 \\
10 & $326234 \mathrm{NS}$ & BSSS \\
\hline
\end{tabular}

replicate, and a photoperiod was maintained at $16 \mathrm{~h}$ (light) $/ 8 \mathrm{~h}$ (dark). One set of pots was placed at $25^{\circ} \mathrm{C}$ (optimal temperature), while the other set was placed at $15^{\circ} \mathrm{C}$ (suboptimal temperature) during the whole period of study. Seedling emergence was recorded daily, for 7 days. The emergence was counted when seedling coleoptile peeked from moistened sand.

To investigate final germination (FG), seeds were dug out from the sand on the 7 th day, and examined for the evidence of germination. Seeds were considered germinated when the radicle was $2 \mathrm{~mm}$ long.

Time to $50 \%$ emergence $\left(\mathrm{E}_{50}\right)$ was calculated with the formula (Coolbear et al., 1984):

$\mathrm{E}_{50}=\mathrm{t}_{\mathrm{i}}+\left(\mathrm{N} / 2-\mathrm{n}_{\mathrm{i}}\right)\left(\mathrm{t}_{\mathrm{j}}-\mathrm{t}_{\mathrm{i}}\right) /\left(\mathrm{n}_{\mathrm{j}}-\mathrm{n}_{\mathrm{i}}\right)$

where $\mathrm{N}$ is the final number of emerged seeds, $n_{j}$ and $n_{i}$ are the cumulative number of seeds emerged by adjacent counts at times $t_{j}$ and $t_{i}$, respectively, when $n_{i}<N / 2<n_{j}$.

The vigor index (VI) was calculated according to the following formula (Abdul-Baki and Anderson, 1973):

$\mathrm{VI}=$ seedling length $(\mathrm{cm}) \times \mathrm{FG}$

On the 7 th day seedlings were carefully removed from the sand and washed in tap water. Seedling length (SL) and fresh weight (SW) of 10 seedlings per replicate were recorded and averaged.

Software $\mathrm{R}$ and STATISTICA 12 were used for statistical analysis. Data were processed with two-way ANOVA. Means were compared using LSD test $(\mathrm{P}=0.05)$. Data were graphically presented using GT biplot (Yan \& Rajcan, 2002). Spearman's rank correlations of the analysed traits were calculated.

\section{Results and Discussion}

The results of our study show that seed priming treatments improved certain examined seedling growth traits under optimal temperature conditions $\left(25^{\circ} \mathrm{C}\right)$. Both priming treatments (hydro and $\mathrm{KNO}_{3}$ ) shortened $\mathrm{E}_{50}$ in genotypes 3 and 4, and hydropriming shortened this time also in genotypes 5 and 6 (Figure 1A). Seed priming with $\mathrm{KNO}_{3}$ prolonged $\mathrm{E}_{50}$ in genotype 6 . Priming treatments also had certain beneficial effects on early seedling growth under suboptimal temperatures $\left(15^{\circ} \mathrm{C}\right) . \mathrm{E}_{50}$ was shortened only in genotype 5 , with both priming treatments (Figure 1D). Hydropriming shortened this trait in genotypes 3 and 6 . In genotype 2 only $\mathrm{KNO}_{3}$ priming shortened $\mathrm{E}_{50}$.

Seed priming had no beneficial effect on FG at optimal temperature. Moreover, some negative effects were recorded (Figure 1B). Priming with $\mathrm{KNO}_{3}$ decreased FG in genotypes 5 and 8, while hydropriming diminished this trait in genotype 10. At suboptimal temperature FG was increased with both priming treatments in genotype 7 , and decreased with $\mathrm{KNO}_{3}$ priming in genotype 9 (Figure 1E). 

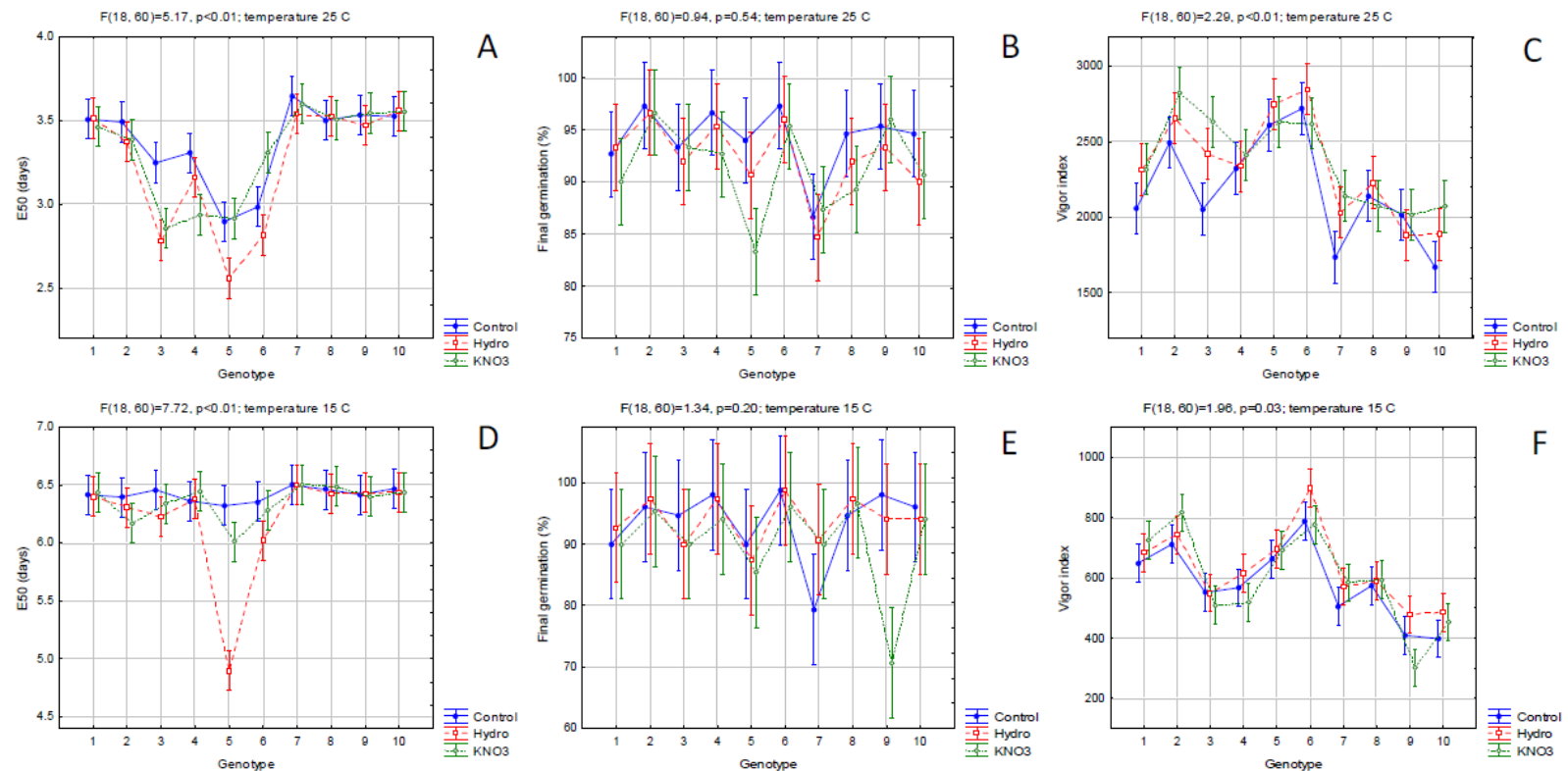

Figure 1. The effect of seed priming (control, hydropriming and KNO3 priming) on seedling growth traits of 10 maize inbred lines. Figure displays means \pm LSD $(P=0.05)$ of time to $50 \%$ of seedling emergence- $\mathrm{E}_{50}(\mathrm{~A})$, final germination- $\mathrm{FG}(\mathrm{B})$, vigor indexVI (C) at optimal temperature $\left(25^{\circ} \mathrm{C}\right)$ and $\mathrm{E}_{50}(\mathrm{D}), \mathrm{FG}(\mathrm{E})$ and VI $(\mathrm{F})$ at suboptimal temperature $\left(15^{\circ} \mathrm{C}\right)$.
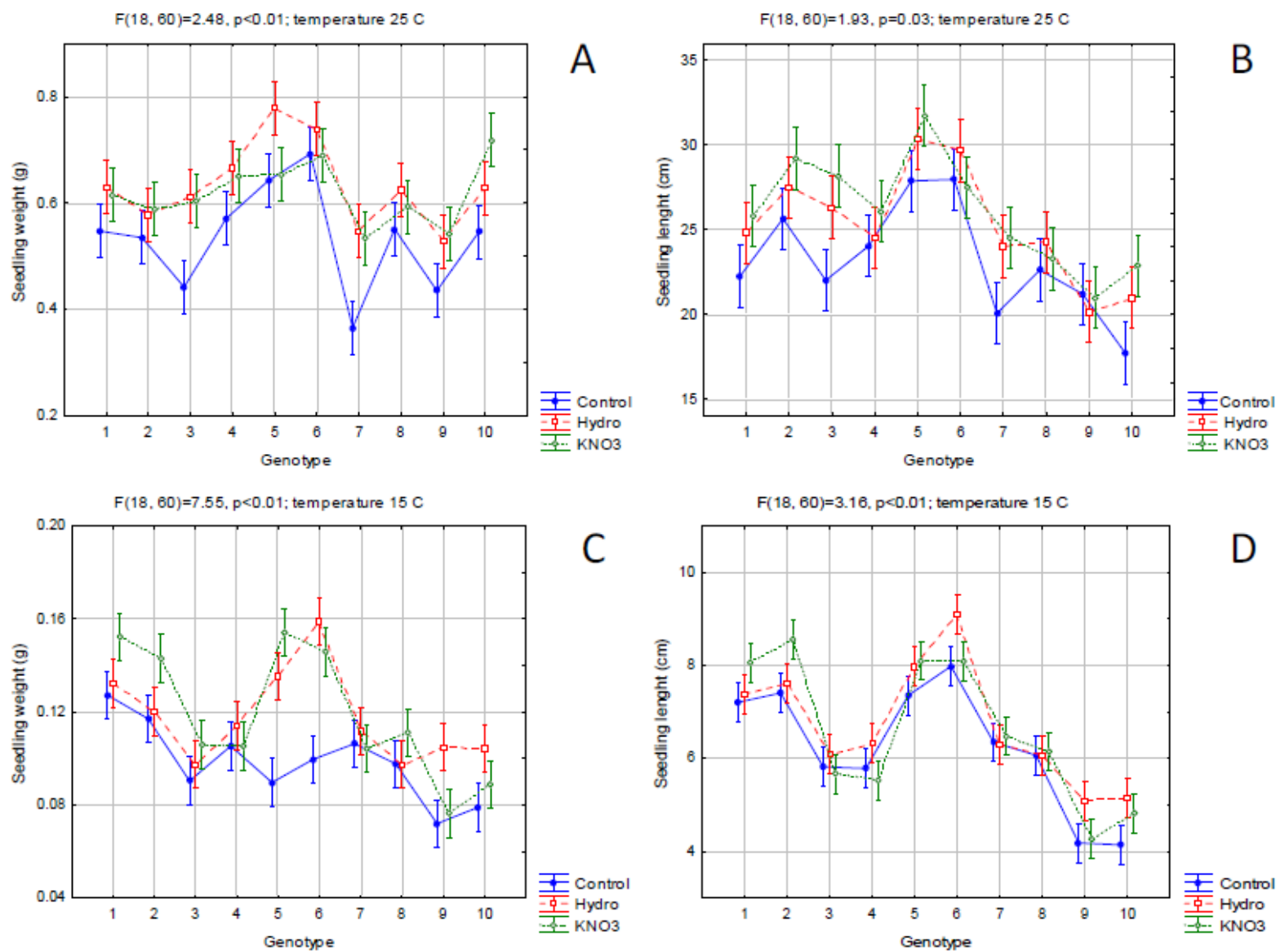

Figure 2. The effect of seed priming (control, hydropriming and $\mathrm{KNO} 3$ priming) on seedling growth traits of 10 maize inbred lines. Figure displays means \pm LSD $(P=0.05)$ of seedling weight- $S W(A)$, seedling length-SL $(B)$ at optimal temperature $\left(25^{\circ} \mathrm{C}\right)$, $\mathrm{SW}(\mathrm{C})$ and $\mathrm{SL}$ at suboptimal temperature $\left(15^{\circ} \mathrm{C}\right)$. 
In genotypes 1, 3, 7 and 10, at optimal temperature, both priming treatments enhanced VI, while in genotype 2 only $\mathrm{KNO}_{3}$ priming treatment increased this trait (Figure 1C). At suboptimal temperature, both priming treatments improved VI in genotype 7 (Figure 1F). This trait in genotypes 6,9 and 10 was increased only with hydropriming. $\mathrm{KNO}_{3}$ priming increased VI in genotypes 1 and 2, and decreased it in genotype 9 at suboptimal temperature.

At optimal temperature, SW increased in genotypes 1, 3, 4, 7, 9, 10 with both priming treatments (Figure 2A). Hydropriming also increased this trait in genotypes 5 and 8 , and $\mathrm{KNO}_{3}$ priming increased it in genotype 2 . At suboptimal temperature, both priming treatments enhanced SW in genotypes 5 and 6 (Figure 2C). In genotypes 9 and 10 only hydropriming increased SW, while in genotypes 1,2, 3 and $8, \mathrm{SW}$ was enhanced only with $\mathrm{KNO}_{3}$ priming.

At optimal temperature, both priming treatments increased SL in genotypes 1, 2, 3, 5, 7 and 10, while in genotype 4, only $\mathrm{KNO}_{3}$ treatment improved this trait (Figure 2B).

SL was increased at suboptimal temperature with both priming treatments in genotypes 5 and 10 (Figure 2D). Only hydropriming enhanced SL in genotypes 4, 6 and 9. SL was increased only with $\mathrm{KNO}_{3}$ priming in genotypes 1 and 2 .

A GT biplot (Figures 3A and 3B) was created to explore the relationship among the studied traits, in order to identify redundantly measured traits and to visualize the genotype profiles of traits (Yan \& Tinker, 2006). At optimal temperature (Figure 3A), 63.59\% of total variation was explained with first (PC1) and $20.44 \%$ with second principal component (PC2). In GT biplot, correlation coefficient between any two traits is approximated by the cosine of the angle between their vectors, so that $r=\cos 180^{\circ}=-1, \cos 0^{\circ}=1$, and $\cos 90^{\circ}=$ 0 (Yan \& Rajcan, 2002). PC1 discriminates $\mathrm{E}_{50}$ from other traits and PC2 discriminates $\mathrm{E}_{50}, \mathrm{FG}$ and VI from SW and SL. Biplot revealed strong positive association among VI, SW and SL, as indicated by the acute angles between their vectors. These traits were negatively associated with $\mathrm{E}_{50}$, as indicated by the obtuse angle. The vector of FG was perpendicular to all other vectors, pointing to zero association. Correlation coefficients from Table 2 were in line with associations obtained by biplot. Highly significant positive correlation was determined among VI, SW and SL. These traits were in highly significant negative correlation with $\mathrm{E}_{50}$. Weak correlation was determined between FG and all other traits.

The distance between the genotype and biplot origin represents the vector length of a genotype, and that is the measure of the genotype's peculiarity, i.e. how it differs from an "average" genotype (Yan \& Frégeau-Reid, 2008). In this study, genotypes with longer vector that formed acute angles with desirable traits could be marked as better ones. Also, the effects of certain treatments, such as seed priming could be observed. For clearer picture, biplot can be modified to show vectors of individual traits with genotypes projection on them (Figures $3 \mathrm{~B}$ and $4 \mathrm{~B}$ ). In Figure 3B, the effect of priming treatment on $\mathrm{E}_{50}$ can be easily observed. For example, ANOVA showed that hydropriming shortened $\mathrm{E}_{50}$ at optimal temperature in genotypes 3, 4, 5 and 6 . On biplot, 3:H, 4:H 5:H and $6: \mathrm{H}$ project on more negative end of $\mathrm{E}_{50}$ vector than their control treatments (:C). Also, it can be seen that $\mathrm{KNO}_{3}$ priming shortened $\mathrm{E}_{50}$ in genotypes 3 and 4, and prolonged this time in genotype 6 . Some differences

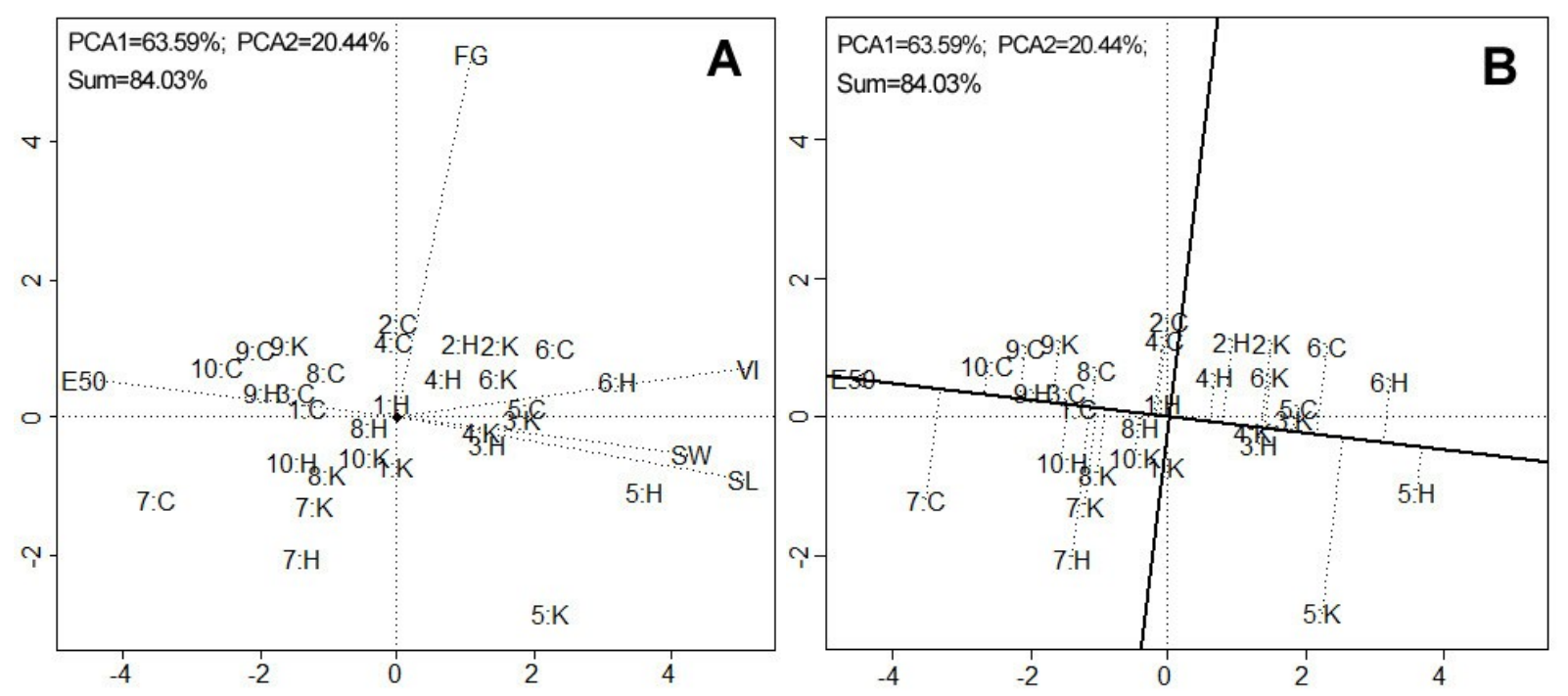

Figure 3. (A) Genotype by trait (GT) biplot of 10 maize inbred lines subjected to different priming treatments (C: control, H: hydropriming, K: KNO3 priming) for five early seedling growth traits ( $\mathrm{E}_{50}$ : time to $50 \%$ of seedling emergence, SW: seedling weight, SL: seedling length, FG: final germination, VI: vigor index) and (B) the same genotype by trait (GT) biplot modified to concentrate on one trait profiles $\left(\mathrm{E}_{50}\right)$ at optimal temperature $\left(25^{\circ} \mathrm{C}\right)$. 
between ANOVA and biplot display were recorded. On biplot, in genotype 7, high improvement in $E_{50}$ was obtained with both priming treatments. However, ANOVA did not detect any improvements (Figure 1A).

At suboptimal temperature, $60.66 \%$ of total variation was explained with PC1 and $23.11 \%$ with PC2 (Figure 4A). PC1 and PC2 discriminate all traits in the same way as at optimal temperature. Also, similar associations were obtained. VI, SL and SW were strongly associated. These traits had weak positive to nearly zero association with FG and negative association with $\mathrm{E}_{50}$. This negative association was weaker at optimal temperature. Weak positive association was obtained between FG and $\mathrm{E}_{50}$. In this case, also, the coefficients of correlation mainly confirmed the results obtained by biplot (Table 2). Figure 4B displays genotypes performance on SW at suboptimal temperature. This biplot showed the beneficial effect of seed priming treatments on SW, previously determined with ANOVA. For example, 5:H, 6:H, 5:K and 6:K have better performance on SW than 5:C and 6:C.

The results of this study showed that seed priming can improve early seedling growth under optimal and suboptimal temperature conditions. No specific pattern reaction to priming treatments among the different heterotic groups was noticed. At optimal temperature, seed priming treatments had high beneficial effects on SW and SL. One or another priming treatment improved SW in nine genotypes and SL in seven genotypes. In half of them, priming improved VI and $\mathrm{E}_{50}$. Seed priming showed no beneficial effect on FG. In accordance with this, Kausar et al. (2009) reported that priming did not affect seed germination in sunflower. In few genotypes, priming decreased FG. The negative effect was also recorded in $\mathrm{E}_{50}$ where $\mathrm{KNO}_{3}$ priming prolonged this time in one genotype. Similar situation was recorded at suboptimal temperature. Dezfuli et al. (2008) also showed that some priming treatments could decrease FG and other early seedling growth traits. Tzortzakis (2009) showed positive effect of seed priming (KNO3) on endive and chicory shoot and root fresh weight. Canak et al. (2016) found that seed priming treatments had more improving effects on the studied maze seed and seedling traits under suboptimal than under optimal conditions. Vujošević et al. (2017) concluded that there were differences in response of maize genotypes to applied pesticide treatments on seed, as well as to a specific treatment at optimal and suboptimal temperatures.

Biplot analysis was used to examine the association among the studied traits and to assess the effect of priming treatments. High percentage of explained variation with biplots indicates high accurse of the obtained results (Yan \& Frégeau-Reid, 2008). The association among traits was very similar at both temperatures. VI, SW and SL were strongly positively associated. Longer seedlings are usually heavier, and that can explain strong association between SL and SW. Seed vigor is an important seed trait, since this trait indicates a potentially fast and uniform seedling emergence, and appropriate crop establishment during the period of early growth (Mondo et al., 2013). VI is directly proportional to SL $(\mathrm{VI}=\mathrm{SL} * \mathrm{FG})$, which can explain their positive association. $\mathrm{E}_{50}$ is one of the commonly used measures of the emergence rate and it represents the period during which $50 \%$ of the seeds emerged. High values of this parameter indicate a slow
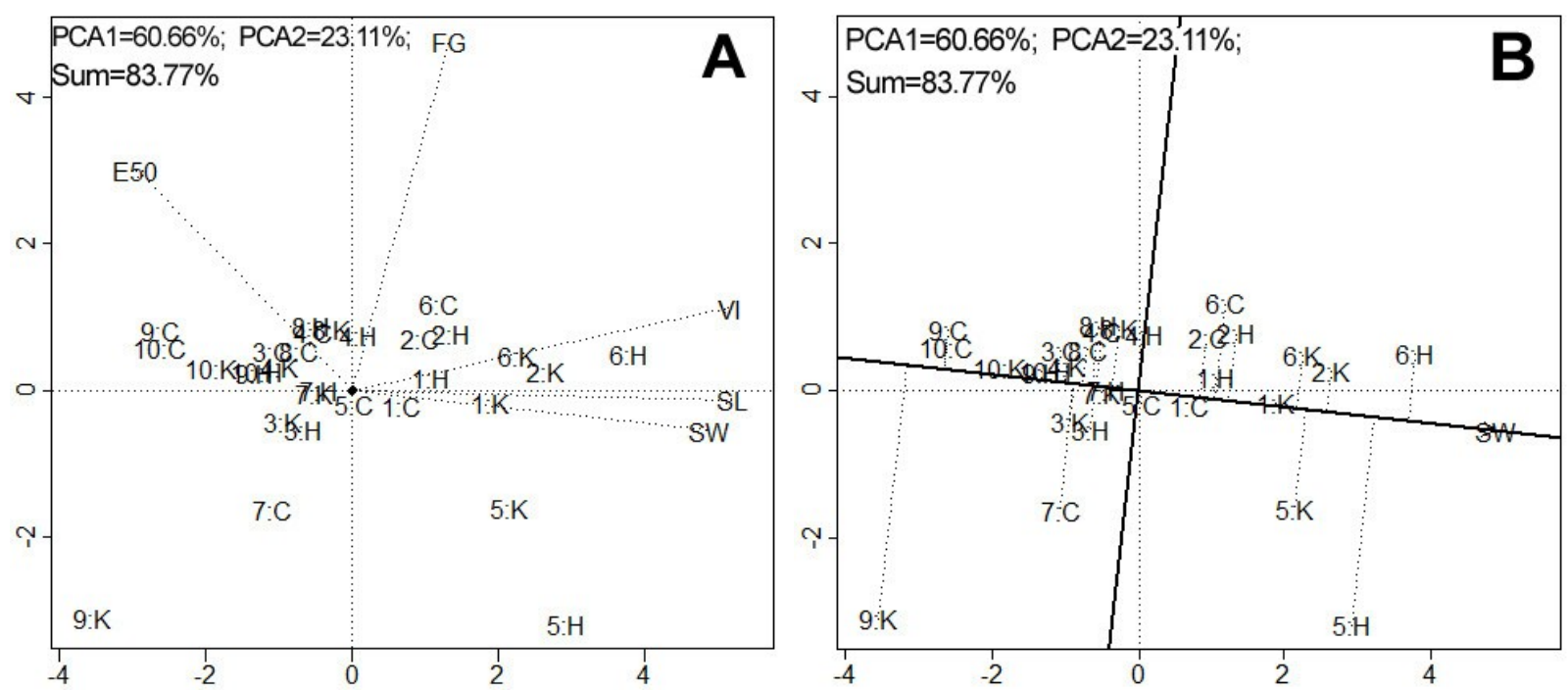

Figure 4. (A) Genotype by trait (GT) biplot of 10 maize inbred lines subjected to different priming treatments (C: control, H: hydropriming, $\mathrm{K}: \mathrm{KNO}_{3}$ priming) for five early seedling growth traits $\left(\mathrm{E}_{50}\right.$ : time to $50 \%$ of seedling emergence, SW: seedling weight, SL: seedling length, FG: final germination, VI: vigour index) and (B) the same genotype by trait (GT) biplot modified to concentrate on one trait profiles $(\mathrm{SW})$ at suboptimal temperature $\left(15^{\circ} \mathrm{C}\right)$. 
Table 2. Correlations between maize seedling growth traits: time to $50 \%$ seedling emergence $\left(\mathrm{E}_{50}\right)$, seedling weight (SW), seedling length (SL), final germination FG) and vigor index $(\mathrm{VI})$ at optimal $\left(25^{\circ} \mathrm{C}\right)$ and suboptimal temperature $\left(15^{\circ} \mathrm{C}\right) .(1)$

\begin{tabular}{cclccc}
\hline Temperature & Traits & $\mathrm{E}_{50}$ & SW & SL & FG \\
\hline \multirow{3}{*}{$25^{\circ} \mathrm{C}$} & $\mathrm{SW}$ & $-0.52^{* *}$ & - & - & - \\
& $\mathrm{SL}$ & $-0.75^{* *}$ & $0.66^{* *}$ & - & - \\
& $\mathrm{FG}$ & -0.27 & -0.01 & 0.16 & - \\
& $\mathrm{VI}$ & $-0.77^{* *}$ & $0.63^{* *}$ & $0.97^{* *}$ & 0.35 \\
\hline \multirow{3}{*}{$15^{\circ} \mathrm{C}$} & $\mathrm{SW}$ & $-0.42^{*}$ & - & - & - \\
& $\mathrm{SL}$ & $-0.53^{* *}$ & $0.80^{* *}$ & - & - \\
& $\mathrm{FG}$ & -0.07 & -0.04 & 0.01 & - \\
& $\mathrm{VI}$ & $-0.55^{* *}$ & $0.74^{* *}$ & $0.95^{* *}$ & 0.25 \\
\hline
\end{tabular}

(1) Spearman's rank correlations; $*$ significant at $5 \%$ probability level; $* *$ significant at $1 \%$ probability level

rate of germination. Seed priming treatments shortened duration of $E_{50}$ under optimal and suboptimal temperature conditions in certain maize genotypes, as was previously reported in the work of Farooq et al. (2008). The shortening of $E_{50}$ actually increased the speed of emergence, traits that are especially important for rapid and appropriate crop establishment in stressful conditions, such as low temperature. For example, rapid emergence decreases the period of seed exposure to the attack of soil pathogens (Dalling et al., 2011; Beckstead et al., 2007). Since the early and rapid germination provides more time for seedling growth, $\mathrm{E}_{50}$ was in negative association with growth parameters such as shoot SL, SV and VI at both temperatures. FG had weak or no association with other traits. The coefficients of correlation in both temperatures were in agreement with the associations obtained by biplot analysis. Comparing the results of biplot and correlation coefficients, Dehghani et al. (2008) obtained similar agreement.

The effect of priming treatment on seedling growth traits was assessed with ANOVA and biplot. Similar results were obtained, with minor differences. Also, genotype response to environment, or in this case, traits, in reality is multivariate situation but it is considered to be an univariate problem by parametric methods (Alwala et al., 2010). Biplot's display, also, has a certain disadvantage. Biplot cannot detect the significance of associations. For those purposes, it is recommended to combine it with parametric methods like ANOVA.

\section{Conclusion}

Seed priming can improve seedling growth at optimal and suboptimal temperature. There are differences in genotype response to various seed priming solutions. Observed differences in germination and seedling growth represent useful information for the selection of adapted maize inbred line and adjustment of priming treatment for sowing in different temperature conditions.

Genotype by trait biplot could be easily used for assessing the effect of seed priming, or some other treatment, on seedling growth traits. This biplot can also be used for perceiving the associations among the seedling growth traits.

\section{References}

Abdul-Baki, A.A., \& Anderson, J.D. (1973). Vigor determination in soybean by multiple criteria. Crop Science, 13, 630-633.

Alwala, S., Kwolek, T., McPherson, M., Pellow, J., \& Meyer, D. (2010). A comprehensive comparison between Eberhart and Russell joint regression and GGE biplot analyses to identify stable and high yielding maize hybrids. Field Crops Research, 119, 225-230.

Badar-uz-Zaman, Ali, A., Hyder, S.I., Arshadullah, M., \& Bhatti, S.U. (2012). Potassium chloride as a nutrient seed primer to enhance salt-tolerance in maize. Pesquisa Agropecuária Brasileira, 47, 1181-1184.

Beckstead, J., Meyer, S.E., Molder, C.J., \& Smith, C. (2007). A race for survival: can Bromus tectorum seeds escape Pyrenophora semeniperda-caused mortality by germinating quickly? Annals of Botany, 99, 907-914.

Bejandi, T.K., Sedghi, M., Sharifi, R.S., Namvar, A., \& Molaei, P. (2009). Seed priming and sulfur effects on soybean cell membrane stability and yield in saline soil. Pesquisa Agropecuária Brasileira, 44, 1114-1117.

Čanak, P., Jocković, M., Ćirić, M., Mirosavljević, M., \& Miklič, V. (2014). Effect of seed priming with various concentrations of $\mathrm{KNO}_{3}$ on sunflower seed germination parameters in in vitro drought conditions. Research on Crops, 15, 154-158.

Čanak, P., Mirosavljević, M., Ćirić, M., Kešeli, J., Vujošević, B., Stanisavljević, D., \& Mitrović, B. (2016). Effect of seed priming on seed vigor and early seedling growth in maize under optimal and suboptimal temperature conditions. Selekcija i semenarstvo, 22(1), 17-25.

Casenave, E.C., \& Toselli, M.E. (2007). Hydropriming as a pretreatment for cotton germination under thermal and water stress conditions. Seed Science and Technology, 35, 88-98.

Chen, K., Arora, R., \& Arora, U. (2010). Osmopriming of spinach (Spinacia oleracea L. cv. Bloomsdale) seeds and germination performance under temperature and water stress. Seed Science and Technology, 38, 36-48.

Coolbear, P., Francis, A., \& Grierson, D. (1984). The effect of low temperature pre-sowing treatment under the germination performance and membrane integrity of artificially aged tomato seeds. Journal of Experimental Botany, 35, 1609-1617.

Dalling, J.W., Davis, A.S., Schutte, B.J., \& Arnold, A.E. (2011). Seed survival in soil: interacting effects of predation, dormancy and the soil microbial community. Journal of Ecology, 99, 89-95.

Dehghani, H., Omidi, H., \& Sabaghnia, N. (2008). Graphic analysis of trait relations of rapeseed using the biplot method. Agronomy Journal, 100, 1443-1449.

Dezfuli, P.M., Sharif-Zadeh, F., \& Janmohammadi, M. (2008). Influence of priming techniques on seed germination behavior of maize inbred lines (Zea mays L.). ARPN Journal of Agricultural and Biological Science, 3, 22-25.

Farooq, M., Aziz, T., Hussain, M., Rehman, H., Jabran, K., \& Khan, M.B. (2008). Glycinebetaine improves chilling tolerance in hybrid maize. Journal of Agronomy and Crop Science, 194, 152-160.

Foti, R., Abureni, K., Tigere, A., Gotosa, J., \& Gere, J. (2008). The efficacy of different seed priming osmotica on the establishment of maize (Zea mays L.) caryopses. Journal of Arid Environments, 72, 1127-1130. 
Guan, Y.J., Hu, J., Wang, X.J., \& Shao, C.X. (2009). Seed priming with chitosan improves maize germination and seedling growth in relation to physiological changes under low temperature stress. Journal of Zhejiang University Science B, 10, 427-433.

Jafar, M.Z., Farooq, M., Cheema, M.A., Afzal, I., Basra, S.M.A., Wahid, M.A., Aziz, T., \& Shahid, M. (2012). Improving the performance of wheat by seed priming under saline conditions. Journal of Agronomy and Crop Science, 198, 38-45.

Jolliffe, I.T. (2002). Principal Component Analysis. New York: Springer.

Kausar, M., Mahmood, T., Basra, S.M.A., \& Arshad, M. (2009). Invigoration of low vigor sunflower hybrids by seed priming. International Journal of Agriculture and Biology, 11, 521-528.

Mondo, V.H.V., Cicero, S.M., Dourado-Neto, D., Pupim, T.L., \& Dias, M.A.N. (2013). Seed vigor and initial growth of corn crop. Journal of Seed Science, 35, 64-69.

Pandita, V.K., Anand, A., Nagarajan, S., Seth, R., \& Sinha, S.N. (2010). Solid matrix priming improves seed emergence and crop performance in okra. Seed Science and Technology, 38, 665-674.

Shim, S.I., Moon, J.C., Jang, C.S., Raymer, P., \& Kim, W. (2008). Effect of Potassium Nitrate Priming on Seed Germination of Seashore Paspalum. HortScience, 43, 2259-2262.

Tzortzakis, N. (2009). Effect of pre-sowing treatment on seed germination and seedling vigour in endive and chicory. Hort.Sci. (Prague)36(3), 117-125.
Yan, W., \& Frégeau-Reid, J. (2008). Breeding line selection based on multiple traits. Crop Science, 48, 417-423.

Yan, W., Hunt, L.A., Sheng, Q., \& Szlavnics, Z. (2000). Cultivar evaluation and mega-environment investigation based on GGE biplot. Crop Science, 40, 597-605.

Yan, W., \& Kang, M.S. (2003). GGE biplot analysis: A graphical tool for breeders, geneticists, and agronomists, Boca Raton: CRC Press.

Yan, W., \& Rajcan, I. (2002). Biplot analysis of test sites and trait relations of soybean in Ontario. Crop Science, 42, 11-20.

Yan, W., \& Tinker, N.A. (2006). Biplot analysis of multi-environment trial data: principles and applications. Canadian Journal of Plant Science, 86, 623-645.

Yazdi, S.A.F., Rezvani, M., Mohassel, M.H.R., \& Ghanizadeh, H. (2013). Factors affecting seed germination and seedling emergence of sheep sorrel (Rumex acetosella). Romanian Agricultural Research, 30, 373-380.

Vujošević, B., Kešelj, J., Ilić, N., Mirosavljević, M., Stanisavljević, D., Mitrović, B., \& Canak, P. (2017). Effect of different seed treatments on maize seed germination parameters under optimal and suboptimal temperature conditions. Ratarstvo i povrtarstvo, 54 (3), 99-103.

\section{Biplot analiza uticaja prajminga semena na početni porast ponika kukuruza}

\section{Petar Čanak · Milan Mirosavljević · Miroslav Zorić · Mihajlo Ćirić · Bojana Vujošević · Bojan Mitrović · Dušan Stanisavljević}

Sažetak: Cilj ovog ispitivanja bilo je utvrđivanje uticaja prajming tretmana i genotipa na klijanje i rani porast ponika kukuruza, kao i sagledavanje povezanosti ovih osobina. Takođe, analizirana je mogućnost primene GT biplot metodologije u ovom tipu ispitivanja. Prajming tretman se sastojao od potapanja semena deset inbred linija kukuruza u vodu (hidroprajming) i rastvor $\mathrm{KNO}_{3}$. Seme je zatim posejano u posude sa vlažnim sterilnom peskom i stavljeno na suboptimalnu $\left(15^{\circ} \mathrm{C}\right)$ i optimalnu temperaturu $\left(25^{\circ} \mathrm{C}\right)$ u trajanju od 7 dana. Nakon toga je izmerena dužina i masa ponika, utvrđena je klijavost i izračunato vreme potrebno za 50\% nicanja, kao i vigor indeks. Rezultati su pokazali da početni porast ponika na obe temperature može biti poboljšan prajmingom semena. Primećena je različita reakcija linija na korišćcene prajming tretmane. Ove razlike predstavljaju korisnu informaciju za izbor odgovarajuće inbred linije i pogodnog prajming tretmana za setvu u različitim temperaturnim uslovima. Ispitivanje je pokazalo da se biplot analiza može koristiti kao brz vizuelni metod za proučavanje efekta prajminga ili nekog drugog tretmana semena na različite parametre klijanja, nicanja i početnog porasta ponika. Takođe, ova analiza se može koristiti i za sagledavanje veze između ispitivanih osobina.

Ključne reči: genotipovi, hidroprajming, kukuruz, ponik, prajming, rastvor, seme 